\title{
Effect of post-exercise ingestion of different molecular weight carbohydrate solutions. Part III: Power output during a subsequent resistance training bout
}

\author{
Leighsa E Van Eck ${ }^{1 *}$, Anthony L Almada ${ }^{2}$, Margaret T Jones ${ }^{3}$, Andrew Jagim4 ${ }^{4}$ Joel Mitchell ${ }^{1}$, Jonathan M Oliver ${ }^{1}$
}

From The Twelfth International Society of Sports Nutrition (ISSN) Conference and Expo

Austin, TX, USA. 11-13 June 2015

\section{Background}

To maximize power adaptations, resistance training (RT) should be performed at maximal power output. In sports where more than one training bout is necessary in a day, subsequent RT may be limited by muscle glycogen, resulting in lower power output. High molecular weight (HMW) carbohydrate $(\mathrm{CHO})$ solutions have been shown to result in greater glycogen re-synthesis rates, and greater work output during a subsequent cycling time trial compared to a low molecular weight (LMW) $\mathrm{CHO}$ solution. However, the effect of a HMW CHO on RT power output following exhaustive exercise is unknown.

\section{Methods}

Sixteen resistance trained men (mean \pm SD; $23 \pm 3$ years; $176.7 \pm 9.8 \mathrm{~cm} ; 88.2 \pm 8.6 \mathrm{~kg} ; 12.1 \pm 5.6 \%$ fat) participated in this study. One-repetition maximum (1RM) back squat (153.3 $\pm 53.6 \mathrm{~kg} ; 1.7 \pm 0.21 \mathrm{RM}$ :body mass), and $\mathrm{VO}_{2} \max \left(37.4 \pm 4.3 \mathrm{ml} \cdot \mathrm{kg} \cdot \mathrm{min}^{-1}\right)$ were initially assessed in order to prescribe exercise intensities during experimental trials. In a double-blind, placebo-controlled, randomized cross over design consisting of three testing sessions separated by one week, subjects completed a glycogen depleting exercise bout on a cycle ergometer. Immediately post-exercise, subjects ingested a placebo (PLA), or a LMW or HMW CHO solution (10\%) providing $1.2 \mathrm{~kg} \cdot \mathrm{bw}^{-1} \mathrm{CHO}$, assigned randomly. Two hours post-ingestion, subjects performed 5 sets of 10 repetitions back squat $(75 \% 1 \mathrm{RM})$ "as explosively as possible". If subjects paused for more than 2 seconds or were unable to

'Department of Kinesiology, Texas Christian University, Fort Worth, TX 76129, USA

Full list of author information is available at the end of the article complete a rep, resistance was lowered by $13.6 \mathrm{~kg}$. Kinematic and kinetic measurements were sampled at 1000 $\mathrm{Hz}$ via force plate and two linear position transducers.

\section{Results}

Average power following ingestion did not differ between CHO solutions until Set $4(\mathrm{p}=0.108)$ and Set $5(\mathrm{p}=$ 0.083). Average power collapsed across the latter Sets was greater following ingestion of the HMW solution (Set 4, $1216 \pm 97 \mathrm{~W}$; Set 5, $1143 \pm 102 \mathrm{~W}$ ) compared to PLA (Set 4, $1066 \pm 80 \mathrm{~W}: \mathrm{p}=0.037$; Set 5, $1019 \pm 89 \mathrm{~W}$ : $\mathrm{p}=0.048)$, but not compared to ingestion of LMW $($ Set $4,1160 \pm 79 \mathrm{~W}: \mathrm{p}=0.355$; Set $5,1131 \pm 92 \mathrm{~W}: \mathrm{p}=$ $0.852)$. No difference was observed between LMW and PLA (Set 4, p = 0.275; Set 5, p = 0.077). The difference in average power was driven by velocity, as similar trends were observed in Set 4 and $5(\mathrm{p}=0.100$ and $\mathrm{p}=0.066$, respectively). Average velocity was higher following ingestion of HMW (Set 4, $0.63 \pm 0.03 \mathrm{~m} \cdot \mathrm{s}^{-1}$; Set 5, $0.62 \pm$ $0.03 \mathrm{~m} \cdot \mathrm{s}^{-1}$ ) compared to PLA (Set $4,0.56 \pm 0.04 \mathrm{~m} \cdot \mathrm{s}^{-1}$ : $\mathrm{p}=0.050 ;$ Set $\left.5,0.56 \pm 0.04 \mathrm{~m} \cdot \mathrm{s}^{-1}: \mathrm{p}=0.032\right)$, but not LMW (Set 4, $0.61 \pm 0.03 \mathrm{~m} \cdot \mathrm{s}^{-1} ; \mathrm{p}=0.422$; Set $5,0.61 \pm$ $\left.0.03 \mathrm{~m} \cdot \mathrm{s}^{-1}: \mathrm{p}=0.074\right)$, with no difference between LMW and PLA (Set $4, p=0.220$; Set $5, p=0.769$ ). HMW conferred a likely beneficial effect in Sets 4 and 5 ( $92.5 \%$ and 88.7\% likelihood, respectively), compared to PLA; while ingestion of LMW conferred only a possibly beneficial effect $(68.7 \%)$ and likely beneficial effect $(83.9 \%)$ in Sets 4 and 5 , respectively.

\section{Conclusions}

These data suggest post-exercise ingestion of a HMW $\mathrm{CHO}$ solution providing $1.2 \mathrm{~kg} \cdot \mathrm{bw}^{-1} \mathrm{CHO}$ may allow 
athletes to sustain power output in a subsequent resistance training session when time between training sessions is limited.

\section{Acknowledgements}

This work was supported in part by Vitargo Global Sciences, LLC.

\section{Authors' details}

'Department of Kinesiology, Texas Christian University, Fort Worth, TX 76129, USA. ${ }^{2}$ Vitargo Global Sciences, LLC, Dana Point, CA 92629, USA. ${ }^{3}$ Health and Human Performance Division, George Mason University, Fairfax, VA 22030,

USA. ${ }^{4}$ Exercise \& Sport Science Department, University of Wisconsin - La

Crosse, La Crosse, WI 54601, USA.

Published: 21 September 2015

doi:10.1186/1550-2783-12-S1-P32

Cite this article as: Van Eck et al.: Effect of post-exercise ingestion of different molecular weight carbohydrate solutions. Part III: Power output during a subsequent resistance training bout. Journal of the International Society of Sports Nutrition 2015 12(Suppl 1):P32.

Submit your next manuscript to BioMed Central and take full advantage of:

- Convenient online submission

- Thorough peer review

- No space constraints or color figure charges

- Immediate publication on acceptance

- Inclusion in PubMed, CAS, Scopus and Google Scholar

- Research which is freely available for redistribution

Submit your manuscript at www.biomedcentral.com/submit 